Table 1. Characteristics of granulomatous eruptions associated with MDS: a review of the literature.

\begin{tabular}{|c|c|c|c|c|c|c|c|}
\hline Case & Author & Age/Sex & $\begin{array}{l}\text { Cutaneous } \\
\text { eruption }\end{array}$ & Itching & $\begin{array}{l}\text { Conversion } \\
\text { to AML }\end{array}$ & Treatment & Outcome \\
\hline 1 & & $66 / \mathrm{M}$ & $\begin{array}{l}\text { Widespread } \\
\text { papules }\end{array}$ & ND & + & $\begin{array}{l}\text { Chemotherapy with } \\
\text { doxorubicin, } \\
\text { cytosine arabinoside } \\
\text { and thioguanine }\end{array}$ & $\begin{array}{l}\text { Refractory with } \\
\text { chemotherapy }\end{array}$ \\
\hline 2 & & 71/M & $\begin{array}{l}\text { Widespread } \\
\text { papules }\end{array}$ & ND & - & ND & $\begin{array}{l}\text { Improved within } \\
1 \text { year }\end{array}$ \\
\hline 3 & Katz [3] & $66 / F$ & $\begin{array}{l}\text { Numerous, } \\
\text { well-demarcated, } \\
\text { non-tender, } \\
\text { erythematous } \\
\text { nodules }\end{array}$ & ND & + & $\begin{array}{l}\text { Oral } \\
\text { diphenhydramine, } \\
\text { clobetasol ointment, } \\
\text { triamcinolone } \\
\text { ointment }\end{array}$ & $\begin{array}{l}\text { Improved } \\
\text { (duration: ND) }\end{array}$ \\
\hline 4 & Balin et al. [1] & $71 / \mathrm{M}$ & $\begin{array}{l}\text { Diffuse erythema } \\
\text { and widespread } \\
\text { papules }\end{array}$ & ND & + & Lenalidomide & $\begin{array}{l}\text { Improved within } \\
6 \text { weeks }\end{array}$ \\
\hline 5 & Hagiwara et al. [4] & $65 / \mathrm{M}$ & $\begin{array}{l}\text { Erythroderma with } \\
\text { nodules on the trunk } \\
\text { and extremities }\end{array}$ & + & - & $\begin{array}{l}\text { Oral prednisolone, } \\
\text { nicotinic acid amide } \\
\text { and doxycycline } \\
\text { hydrochloride }\end{array}$ & $\begin{array}{l}\text { Pruritus and } \\
\text { erythema except for } \\
\text { nodules improved } \\
\text { (duration: ND) }\end{array}$ \\
\hline 6 & Our case & $81 / \mathrm{M}$ & $\begin{array}{l}\text { Diffuse erythema } \\
\text { and widespread } \\
\text { papules }\end{array}$ & + & + & Oral tranilast & $\begin{array}{l}\text { Improved within } 3 \\
\text { months } \\
\text { Died } 6 \text { months after } \\
\text { the initiation of } \\
\text { tranilast. }\end{array}$ \\
\hline
\end{tabular}

AML: acute myeloid leukemia; MDS: myelodysplastic syndrome; ND: not described.

Disclosure. Acknowledgments: The authors would like to thank Ms. Yuko Tsukamoto for her help with the immunohistochemical analysis. Financial support: none. Conflict of interest: none.

Department of Dermatology, Shiga
University of Medical Science,
Setatsukinowa, Otsu,
Shiga 520-2192, Japan
<noriki@ @elle.shiga-med.ac.jp>

10. Ine K, Kabashima K, Koga C, Kobayashi M, Tokura Y, Kabashima $K$. Eruptive generalized granuloma annulare presenting with numerous micropapules. Int J Dermatol 2010; 49: 104-5.

doi:10.1684/ejd.2016.2812

1. Balin SJ, Wetter DA, Kurtin PJ, Letendre L, Pittelkow MR. Myelodysplastic syndrome presenting as generalized granulomatous dermatitis. Arch Dermatol 201 1; 147: 331-5.

2. Vestey JP, Turner M, Biddlestone L, McLaren K, Goulden N, Hunter JA. Disseminated cutaneous granulomatous eruptions associated with myelodysplastic syndrome and acute myeloid leukaemia. Clin Exp Dermatol 1993; 18: 559-63

3. Katz KA. Disseminated cutaneous granulomatous eruption occurring in the setting of myelodysplasia. Dermatol Online J 2003; 9: 22.

4. Hagiwara A, Fujimura T, Furudate $S$, et al. Generalized granulomatous dermatitis accompanied by myelodysplastic syndrome. Acta Derm Venereol 2014; 94: 223-4.

5. Kuramoto $Y$, Shindo $Y$, Tagami $H$. Subcutaneous sarcoidosis with extensive caseation necrosis. J Cutan Pathol 1988; 15: 188-90.

6. Al-Mutairi N. Nosology and therapeutic options for lupus miliaris disseminatus faciei. J Dermatol 2011;38: 864-73.

7. Mizuno K, Okamoto $\mathrm{H}$, Horio T. Inhibitory influences of tranilast on multinucleated giant cell formation from monocytes by supernatant of concanavalin A-stimulated mononuclear cells. J Dermatol Sci 2000; 24: 166-70.

8. Yamada $H$, Ide A, Sugiura $M$, Kurihara $S$, Tajima $S$. Treatment of granuloma annulare with tranilast. J Dermatol 1995; 22: 354-6.

9. Araki E, Kambe N, Takahashi K, Miyachi Y, Utani A. Multiple dermatomal daughter lesions of postzoster granuloma. Br J Dermatol 2007; 156: 1369-71.

\section{Proliferating trichilemmal tumour: a com- parison of dermoscopic, ultrasonographic and histopathological features}

Proliferating trichilemmal tumour (PTT) is a rare and usually benign dermal or subcutaneous neoplasm. Some PTTs are difficult to clinically diagnose since the clinical differential diagnoses of PTT range from benign conditions, such as epidermal cyst, to malignant skin tumours, such as basal cell carcinoma (BCC), squamous cell carcinoma (SCC), and malignant PTT [1-3]. The lack of distinguishing dermoscopic and sonographic characteristics of PTT reported in the literature prompted us to report a case of PTT with such findings, which may aid the diagnosis of future cases. A 96-year-old Japanese male presented to a nearby clinic with a one-year history of a nodule in the left parietal region of the scalp. The nodule was not associated with any history of trauma, and was initially asymptomatic. It enlarged progressively, and an ulcer appeared. Two weeks of treatment with oral and topical antibiotics were ineffective, and the patient was referred to our department. His past medical history and family history were unremarkable.

Physical examination revealed a milky red, elastic, hard, $20 \times 11$-mm dome-shaped mobile nodule with an ulcerating lesion (figure 1A). No regional lymphadenopathy

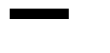




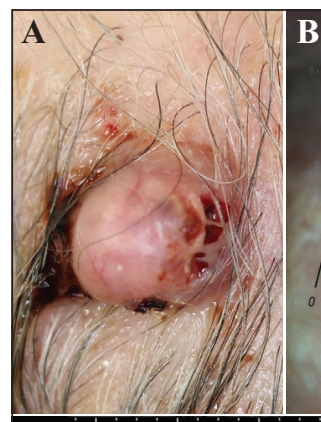

\section{B}
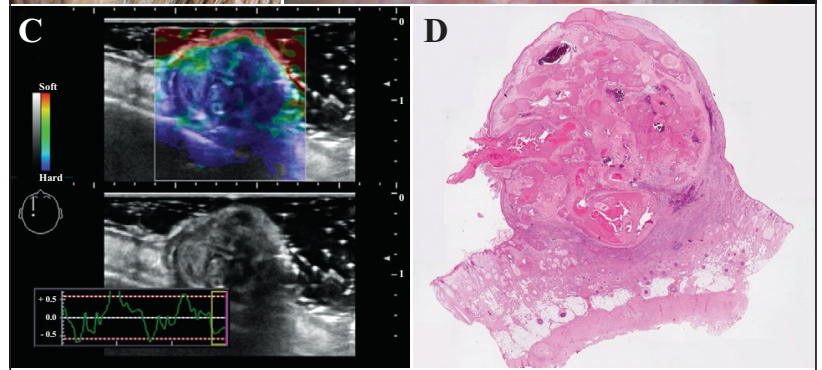

E

F

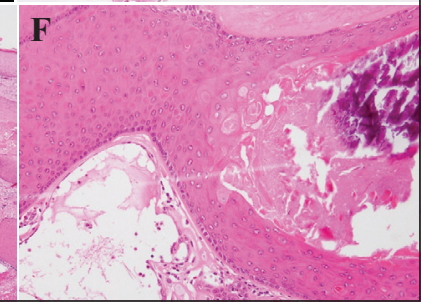

Figure 1. Clinical, dermoscopic, sonographic, and histopathological images of a PTT. A) Milky red, elastic, hard, $20 \times 11$-mm dome-shaped mobile nodule with an ulcer. B) Dermoscopy of the nodule shows arborising vessels (arrows), shiny white areas (asterisks), and purple hue (arrowhead) with multiple shades of yellow background colouration. C) Ultrasonography of the nodule shows a well-defined isoechoic lesion, hyperechoic spots inside the nodule, and hypoechoic thick curved lines from the lower part of the nodule (lower half). No increase in vascularity was found inside the lesion or its periphery. Real-time tissue elastography of the nodule showed that it is harder than the surrounding normal dermal tissue (upper half). D) Low-power view of the nodule with surrounding tissue, consisting of multiple lobules varying in size. E) Medium-power view of the surface of the nodule showing several crypts with keratin mass. Dilation of vessels and thrombosis are present throughout the nodule. The epidermis is atrophic, and subepidermal fibrosis is present. F) Highpower view showing a lobule composed of squamous cells with trichilemmal keratinisation associated with focal calcification in amorphous keratin mass and inflammatory infiltrate. Tumour cells show only mild nuclear atypia and lack stromal infiltration.

was detected. Dermoscopic examination of the nodule showed arborising vessels, shiny white areas, and purple hue with multiple shades of yellow colouration in the background (figure 1B). Ultrasonography of the nodule showed a well-defined isoechoic lesion, hyperechoic spots inside the nodule, and hypoechoic thick curved lines from the lower part of the nodule. No increase in blood flow was found within the lesion or its periphery. Real-time tissue elastography of the nodule showed that it was harder than the surrounding normal dermal tissue (figure $1 C$ ).
Although some of the results of the above examinations were not typical of BCC, we clinically diagnosed the nodule as BCC, since its clinical presentation, arborising vessels observed upon dermoscopic examination, and hyperechoic spots inside the nodule observed on ultrasonography were compatible with adnexal tumours including BCC [4-6].

We excised the nodule with a 3-mm margin. Histopathologically, the nodule was basically demarcated from the surrounding tissue and consisted of multiple lobules varying in size (figure 1D). The surface of the nodule showed several crypts with keratotic plaques. The epidermis was atrophic and subepidermal fibrosis was present. Dilation of vessels and thrombosis were present throughout the nodule (figure 1E). Each lobule was composed of squamous cells with trichilemmal keratinisation associated with focal calcification in amorphous keratin and inflammatory infiltrate. Tumour cells showed only mild nuclear atypia and lacked stromal infiltration (figure $1 F$ ). The nodule was therefore diagnosed as a PTT [1-3].

Differentiating between PTT and other malignant tumours, such as BCC, is important to determine appropriate treatment. In some articles in the literature, dermoscopic [7] and sonographic [8] findings related to PTT are reported, however, to date, there are no such reports which specifically focus on PTT. We therefore compared these findings with the histopathological findings in our case. The arborising vessels correspond to the dilation of superficial dermal vessels. Atrophic epidermis and subepidermal fibrosis are consistent with shiny white areas. A large area of thrombosis in the upper part of the nodule corresponds to the purple hue. The multiple shades of yellow background colouration and hyperechoic spots correspond to keratin mass which varies in size due to trichilemmal keratinisation in the dermal lobules. Hypoechoic thick curved lines from the lower part of the nodule correspond to stroma between lobules.

The arborising vessels are known as one of the significant dermoscopic findings of BCC, however, they may also be found in adnexal tumours [6]. Lallas et al. reported that the presence of the white structure is suggestive of adnexal tumours of follicular origin. They also reported that dermoscopic yellow structures are typically observed in sebaceous tumours with a homogenous yellow background with or without yellow lobules [7]. Bellucci et al. reported that some BCCs also have yellow structures with lobular-like structures [9]. The multiple shades of yellow background colouration in this case of PTT correspond to the keratin mass discussed above, which is unlikely to be found in sebaceous tumours or BCCs. Therefore, we believe that the combination of arborising vessels, shiny white areas, and the multiple shades of yellow background colouration is an important dermoscopic feature which may aid the diagnosis of adnexal tumours, particularly PTT.

Disclosure. Financial support: none. Conflict of interest: none.
Department of Dermatology, Chiba University, 1-8-1 Inohana, Japan <togawa-yk@faculty.chiba-u.jp> Graduate School of Medicine, Chuo-ku, Chiba-shi 260-8670,
Hideaki MIYACHI Yaei TOGAWA Yosuke YAMAMOTO Rena OGUMA Keisuke SUEHIRO Hiroyuki MATSUE 
1. Folpe AL, Reisenauer AK, Mentzel T, Rütten A, Solomon AR. Proliferating trichilemmal tumors: clinicopathologic evaluation is a guide to biologic behavior. J Cutan Pathol 2003; 30: 492-8.

2. Ye J, Nappi O, Swanson PE, Patterson JW, Wick MR. Proliferating pilar tumors: a clinicopathologic study of 76 cases with a proposal for definition of benign and malignant variants. Am J Clin Pathol 2004; 122: 566-74.

3. Satyaprakash AK, Sheehan DJ, Sangüeza OP. Proliferating trichilemmal tumors: a review of the literature. Dermatol Surg 2007; 33: $1102-8$

4. Altamura D, Menzies SW, Argenziano G, et al. Dermatoscopy of basal cell carcinoma: morphologic variability of global and local features and accuracy of diagnosis. J Am Acad Dermatol 2010; 62: 67-75.

5. Wortsman X. Sonography of facial cutaneous basal cell carcinoma: a first-line imaging technique. J Ultrasound Med 2013;32: 567-72.

6. Martín JM, Bella-Navarro R, Jordá E. Vascular patterns in dermoscopy. Actas Dermosifiliogr 2012; 103:357-75.

7. Lallas A, Moscarella E, Argenziano G, et al. Dermoscopy of uncommon skin tumours. Australas J Dermatol 2014; 55:53-62.

8. Wortsman $X$, Wortsman J, Matsuoka L, et al. Sonography in pathologies of scalp and hair. Br J Radiol 2012; 85: 647-55.

9. Bellucci C, Arginelli F, Bassoli S, Magnoni C, Seidenari S. Dermoscopic yellow structures in basal cell carcinoma. J Eur Acad Dermatol Venereol 2014; 28: 651-4.

doi: $10.1684 /$ ejd.2016.2795

\section{CRTC1-MAML2 gene fusion in G-CSF- secreting mucoepidermoid carcinoma: an indicator of favourable prognosis?}

Mucoepidermoid carcinoma (MEC) is histologically characterised as low-, intermediate-, and high-grade [1]. Low-grade tumours rarely transform into high-grade tumours (dedifferentiation) [2,3] and the latter very rarely produce granulocyte colony stimulating factor (G-CSF) $[4,5]$. MEC harbours a characteristic $\mathrm{t}(11 ; 19)(\mathrm{q} 21 ; \mathrm{p} 13)$ translocation; this rearrangement results from the fusion between exon 1 of the gene for CRTC1 (cyclic AMP/cyclic AMP-responsive element-binding protein-regulated transcription coactivator 1) at 19p13 and exons 2-5 of the gene for MAML2 (Mastermind-like family 2) at 11q21 [6]. We report a case of G-CSF-secreting MEC with dedifferentiation, in which we detected the CRTC1-MAML2 fusion gene not only in a low-grade lesion, but also in a dedifferentiated lesion.

A 75-year-old Japanese woman visited her local dermatologist for a swelling of her left cheek in July 2013. An external dental fistula was suspected and a tooth was extracted. The swelling regressed, but a subcutaneous induration and a nodule appeared. Physical examination in our department (at the end of January 2014) showed dark-red erythema and induration in the left preauricular and submandibular area, as well as a $20 \times 16-\mathrm{mm}$ nodule. One month later, the nodule had increased to $35 \times 35 \mathrm{~mm}$ in size and was $10 \mathrm{~mm}$ high (figure 1A). A biopsy specimen from the nodule revealed a poorly differentiated adenocarcinoma. Laboratory analysis revealed increased WBC count $(26.270 / \mu \mathrm{L})$ with $89 \%$ neutrophils, and increased serum levels of CRP $(19 \mathrm{mg} / \mathrm{dL})$. There was no indication of infection and the only remarkable finding was the presence of tumour on CT. Several antibiotics were ineffective. A G-CSF-producing tumour was suspected and, indeed, the serum level of GCSF was $104 \mathrm{pg} / \mathrm{mL}$ (normal: 10.5-57.5 pg/mL). Tumour resection with a $2-\mathrm{cm}$ measurable margin, including the underlying parotid gland and left neck dissection, was performed. A final pathological diagnosis of MEC arising from the parotid gland was made. The basal area of the tumour consisted of mucous cells that formed ductal structures and epidermoid cells in sheets (figures $1 B-D$ ). Mitoses or necrosis were absent, therefore the lesion was considered to be low-grade MEC. The protruding area of the tumour contained highly atypical cells that were proliferating, with loss of adhesion and numerous infiltrating neutrophils (figure 1E). The histological score of this lesion was 9 , and it was classified as high grade, according to the WHO classification of head and neck tumours [1]. This anaplastic component was thought to have dedifferentiated from the low-grade MEC. Some cells, exclusively located in the high-grade area, expressed G-CSF (figures $1 F, G$ ). No evidence of metastasis was found in the dissected lymph nodes. After tumour resection, the number of WBC and the serum levels of CRP and G-CSF returned to within normal range.

To investigate the CRTC1-MAML2 fusion gene, laser microdissection of tissue from both low- and high-grade areas was performed. RNA was extracted for amplification by nested RT-PCR [7]. Products of the fusion gene were detected from both lesions (figure $1 \mathrm{H}$ ).

To our knowledge, only two cases of G-CSF-secreting MEC have been reported; one was metastatic and in the other case, the patient died within three months $[4,5]$. Usually, G-CSF-producing tumours present as advanced and, often, metastatic tumours because G-CSF accelerates malignancy via induction of immune tolerance and angiogenesis [8]. In our case, some anaplastic cells secreted G-CSF, which presumably contributed to the rapid growth of the tumour.

Recent studies revealed that the CRTC1-MAML2 fusion gene can be found in low-, intermediate- and even highgrade MEC based on series of 71,55 and 80 cases of MEC, respectively $[7,9,10]$, although it is unclear whether the fusion gene is of any value as a prognostic indicator. However, among high-grade MECs, translocation-positive tumours had a higher five-year disease-specific survival rate than translocation-negative tumours [9]. Our case is unusual in that the fusion gene was detected in the dedifferentiated component, which might produce G-CSF, a marker of an aggressive tumour. In four cases of dedifferentiated and G-CSF-producing MECs, the presence of the fusion gene was not examined. To date, now two years after surgery, our patient has not relapsed, and the gene marker appears to be a more reliable prognostic indicator than the histological features of the tumour or secretion of G-CSF. Our patient is being monitored by CT and investigated for leukocyte counts and serum levels of CRP and G-CSF.

Disclosure. Financial support: none. Conflict of interest: none. 